\title{
Exploration of an Economic Photovoltaic River to Storage Pumping System Based on PVSyst Simulation
}

\author{
Md. Imran Hossain ${ }^{1}$, S. M. Raisul Islam ${ }^{2, *}$ \\ ${ }^{1}$ Department of Electrical and Electronic Engineering, American International University Bangladesh, Dhaka, Bangladesh \\ ${ }^{2}$ Department of Management Information Systems, University of Dhaka, Dhaka, Bangladesh \\ Email address: \\ imran.eee.aiub@gmail.com (Md. I. Hossain), ismraisul@gmail.com (S. M. R. Islam) \\ ${ }^{*}$ Corresponding author
}

\section{To cite this article:}

Md. Imran Hossain, S. M. Raisul Islam. Exploration of an Economic Photovoltaic River to Storage Pumping System Based on PVSyst Simulation. International Journal of Electrical Components and Energy Conversion. Vol. 4, No. 1, 2018, pp. 33-44.

doi: $10.11648 /$ j.ijecec. 20180401.14

Received: February 2, 2018; Accepted: April 14, 2018; Published: May 17, 2018

\begin{abstract}
Bangladesh is riverine country riddled with numerous rivers and canals. The country's agriculture and overall rural life is centered on its water sources. Being a growing economy, the country is still hindered by power shortages. This paper is intended to simulate and propose a standalone photovoltaic river to storage pumping system for the rural areas of Bangladesh. Most of the farmers in the country irrigate their land using river water through manual labor which is cumbersome, time consuming and overall inefficient. The object of this research work is to develop a system that can draw water from the rivers and store into storage systems such as tanks. This research work was conducted purely through computer simulations. The proposed system for the modeling of the "River to Storage Pumping System" was simulated on PVSyst software. The simulations showed the overall potential of the initiative and the developed computational model of the system can be erected within an approximate $\$ 100$ budget for each standalone system and has a potential to be an effective low cost support for the local agriculture as a standalone system independent from power grid.
\end{abstract}

Keywords: Computational Modeling, Water Storage, Solar Power Systems, PVSyst, Pumping System

\section{Introduction}

Irrigation affects various facets of socio-economic issues of country. The flood controlled lands are referred to as agricultural irrigated land purposely provided with water [2]. Asian agricultural economies have experienced significant upswings in productivity since the Green Revolution in the 1960s. As widely acknowledged, the Green Revolution was made possible through coordinated infusions of vital inputs into the agricultural systems of the region. Irrigation through major and medium canal systems was one of the most crucial inputs to the Green Revolution [1]. Three decades down the line, the Asian economies benefiting from the Revolution have made famines history. However, after the euphoria over this significant achievement subsided, a major gap was identified - irrigation projects have failed to make the desired difference in the lives of its poor, subsistence and marginal farmers [1]. The proposed system will help the farmers to get rid of this problem of irrigation. Bangladesh is considered as a developing economy which has recorded GDP growth above 5\% during the last few years. Microcredit has been a major driver of economic development in Bangladesh and although three fifths of Bangladeshis are employed in the agriculture sector, three quarters of exports revenues come from garment industry. Bangladesh is endowed with plenty of surface water and groundwater resources. Surface water inflows of the country vary from a maximum of about 140,000 cumec in August to a minimum of about 7,000 cumec in February. The alluvial aquifer systems of Bangladesh are some of the most productive groundwater reservoirs. Groundwater in Bangladesh occurs at a very shallow depth where the recent river-borne sediments form prolific aquifers in the floodplains. In the higher terraces, the Barind and Madhupur tracts, the Pleistocene Dupi Tila sands act as aquifers. In the hilly areas, the Pliocene Tipam sands serve as aquifers. The groundwater table over most of Bangladesh lies very close to the surface and fluctuates with 
the annual recharge discharge conditions.

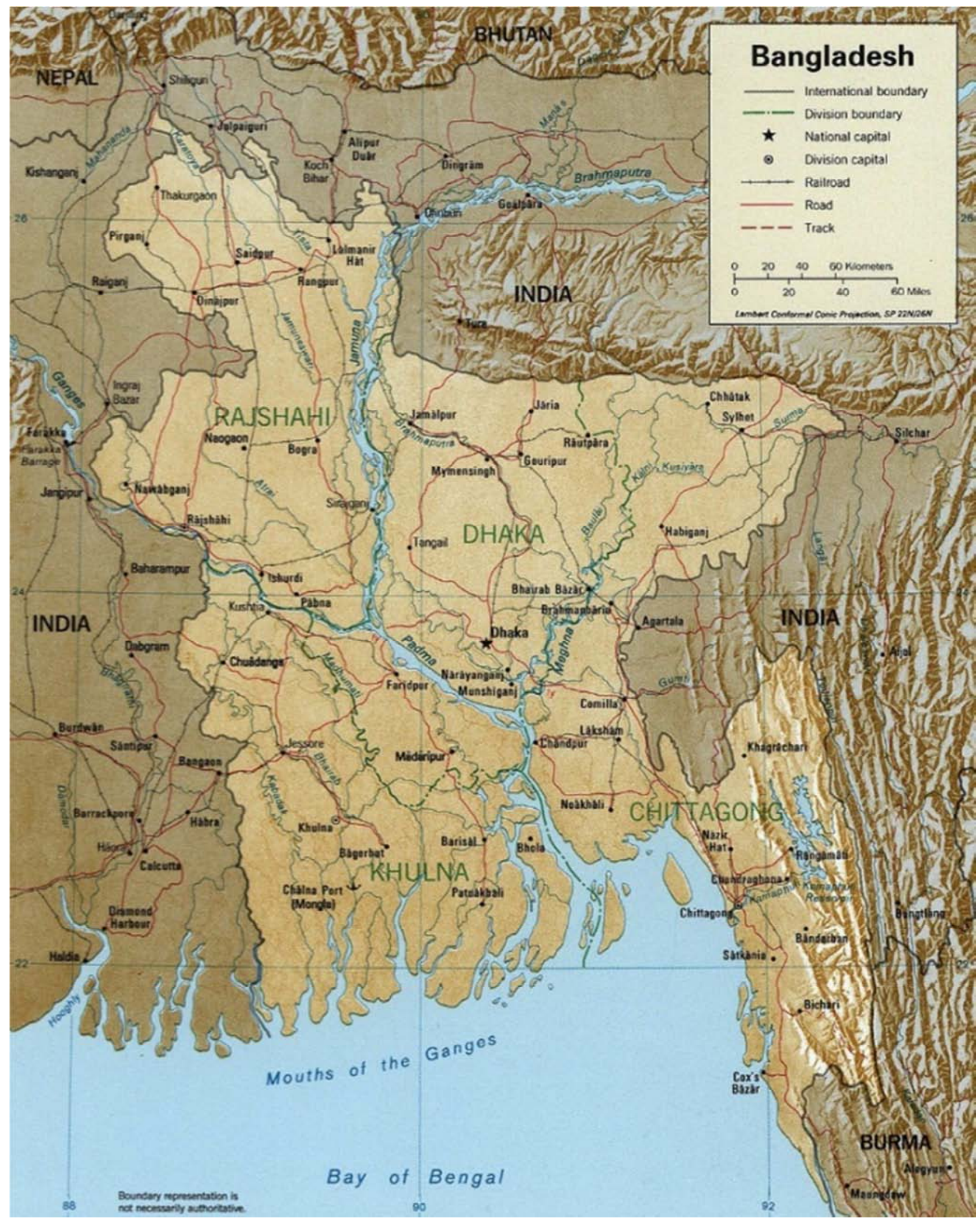

Figure 1. Rivers of Bangladesh (source: wikipedia.com).

The system can be divided into four major networks:

1. Brahmaputra-Jamuna river system,
2. Ganges-Padma river system,

3. Surma-Meghna river system, and 
4. Chittagong region river system.

Bangladesh is blessed with a lot of rivers. Principal rivers are: Padma, Brahmaputra, Jamuna, Surma, Kushiyara, Meghna, Karnafuli, Old Brahmaputra, Arial Khan, Buriganga, Shitalakshya, Tista, Atrai, Gorai, Madhumati, Kobadak, Rupsa-Pashur, Feni. The main challenge is to make the best utilization of this natural resource for the irrigation purpose. That is the primary reasoning to look further in the research of development of cost effective "River to Storage Pumping System". The system will utilize the photovoltaic module to drive to motor for the suction of the water from the river and store it into the storage tank. From there the water will be distributed in the irrigation land. The proposed model uses the storage pump, as the farmers would be able to use the water in the night time or in the gloomy day for the irrigation purpose. This paper actually represents the computational modeling of the "River to Storage Pumping System". First the mathematical model was developed and then the whole system was simulated using the PVSyst software. The diagrams and tables that are represents in the paper are generated while doing the simulation in the software.

\section{Methodology}

For the following paper, various PVsyst internal database and meteo data were utilized. The derived mathematical model was used to simulate the actual system. Using the various data and interchanging the values, the system was tested for real life feasibility and the output results were further mentioned in the following paper.

\section{Software Used: PVsyst}

PVsyst V6.67 is a PC software package for the study, sizing and data analysis of complete PV systems.[14] It deals with grid-connected, stand-alone, pumping and DC-grid (public transportation) PV systems, and includes extensive meteo and PV systems components databases, as well as general solar energy tools. PVsyst V6.67 offers 3 levels of PV system study, roughly corresponding to the different stages in the development of real project:

a) Preliminary design: this is the presizing step of a project.

b) Project design: it aims to perform a thorough system design using detailed hourly simulations.

c) Databases: the databases management - for meteorological data and PV components.

d) Tools: For measured data analysis

\section{Mathematical Modeling}

The following mathematical equations are used for the simulation of the total system.

$$
\begin{gathered}
\mathrm{IT}=\mathrm{SH}_{H} *\left(\left(1-\mathrm{KD}_{\mathrm{D}}\right) * \mathrm{RD}_{\mathrm{D}}+0.5 *(1+\cos \beta) * \mathrm{~K}+0.5 *(1-\cos \beta) * \rho\right) \\
\mathrm{TC}=\left(\mathrm{TA}_{\mathrm{A}}+(\mathrm{TNOCT}-\mathrm{Ts}) *(\mathrm{Io} / \mathrm{IL})\right) \\
\mathrm{Dm}_{\mathrm{m}}=\mathrm{Dp}_{\mathrm{p}} * \mathrm{Dec}^{*} \mathrm{Dim}^{*} \mathrm{DNOCT}_{\mathrm{N}}
\end{gathered}
$$

$$
\begin{gathered}
\text { Dec }=\mathrm{DC}^{*} \text { DMIS } * \text { DT } \\
\text { DC }=\text { Do }+(1-\alpha * \text { TC- TA })) \\
\text { Area }\left(\mathrm{m}^{2}\right)=\mathrm{Load} /(\mathrm{D} * \mathrm{ID}) \\
\mathrm{Q}(\mathrm{Kwh})=(\mathrm{C}+\mathrm{NSR}) * \mathrm{Load} /(\mathrm{DOD} * \mathrm{DB}) \\
\mathrm{DOD}=1-\mathrm{SOC} \\
\mathrm{IT}-\mathrm{ID}=\mathrm{M} * \mathrm{~S} \\
\mathrm{XPV}=\left(\mathrm{X}_{0} *\left(\left(1+\mathrm{g}_{\mathrm{o}}\right) /\left(\mathrm{k}-\mathrm{g}_{\mathrm{o}}\right)\right) *\left(1-\left(\left(1+\mathrm{g}_{\mathrm{o}}\right) /\left(1+\mathrm{k}_{\mathrm{o}}\right)\right) \mathrm{N}\right)\right. \\
\mathrm{RPV}=\mathrm{b} * \mathrm{Q} *(1-\mathrm{s}) * \wedge(\mathrm{N} * \mathrm{i} /(\mathrm{NR}+1))
\end{gathered}
$$

Here,

$\mathrm{B}=$ the tilt angle of the array

$\rho=$ the ground reflectivity

$\mathrm{SH}=$ the total solar irradiation in a horizontal surface

$\mathrm{KD}=$ the diffuse insolation factor

$\mathrm{RD}=$ the daily direct radiation factor

$\mathrm{TNOCT}=$ the nominal operating cell temperature

$\mathrm{TA}=$ the ambient temperature

$\mathrm{TS}=$ the standard temperature

$\mathrm{IO}=$ the standard irradiation

$\mathrm{IL}=$ the local irradiation

Dim=the illumination mismatch efficiency

$\mathrm{DNOCT}=$ the nominal operating cell temperature

$\mathrm{Dp}=$ the module packing density

$\mathrm{Dec}=$ the encapsulated cell efficiency

DMIS $=$ the electrical mismatch

$\mathrm{DT}=$ the optical transmission efficiency

$\mathrm{DC}=$ the cell efficiency

$\mathrm{DO}=$ the bare cell efficiency at standard conditions $\alpha=$ the temperature coefficient of the cell

$\mathrm{TC}=$ the operating temperature of photovoltaic modules

$\mathrm{D}=$ the system efficiency

$\mathrm{ID}=$ the average monthly insolation

$\mathrm{DOD}=$ the depth of discharge

$\mathrm{DB}=$ the battery efficiency

$\mathrm{C}=$ the number of consecutive days

$\mathrm{M}=$ the balancing parameter

$\mathrm{go}=$ the escalation rate for operations \& maintenance (O\&M)

$\mathrm{K}=$ the money interest rate

$\mathrm{N}=$ the system life in years

$\mathrm{X} 0=$ the $\mathrm{O} \& \mathrm{M}$ cost in the first year

$\mathrm{b}=$ the battery unit cost

$\mathrm{Q}=$ the nominal battery capacity

$\mathrm{S}=$ per unit salvage value of replaced battery

\section{Computational Modeling}

The simulation model was created as a unique project under the PVSyst software. The meteo data was collected from the Metronome 7.1 through the software while the location used was Dhaka (Dacca), Bangladesh. The following data were inserted into 3 specific categories of the software which are Orientation, Water Needs and System. The data was inserted in the simulation and after all the 
required data validated by the software, the analysis derived the results which are inserted below as graphs.

1) Water Needs and Hydraulic Details:

Water needs avg.

Yearly water needs

Yearly head avg.

Hydraulic energy

PV needs(very roughly)
D. Pump(s) Model and Layout

Sort pump by power $98 \mathrm{~W}, 6-70 \mathrm{~m}$

Nominal voltage $=24 \mathrm{~V}$

Nominal current $=7 \mathrm{~A}$

E. PV Array

Sort model by power $=60 \mathrm{Wp}$,

$24 \mathrm{~V}$ Array nominal power $=240 \mathrm{Wp}$

Array voltage $\left(50 \hat{\mathrm{A}}^{\circ} \mathrm{c}\right)=29.7 \mathrm{~V}$ Array $=7.1 \mathrm{~A}$

Table 1. PV Module details.

2) Water Needs and Head Definitions:

A. Well Characteristics

Level Depth

$8 \mathrm{~m}$

Pump Depth

$15 \mathrm{~m}$

B. Storage Tank

Volume

$20 \mathrm{~m}^{3}$

Diameter

$3.0 \mathrm{~m}$

Water full height

$2.83 \mathrm{~m}$

Feeding attitude

$5.0 \mathrm{~m}$

C. Hydraulic Circuit

Pipe choice

Piping length

PE20(3/4")

Number of elbow

$18 \mathrm{~m}$

0

Other friction losses
0.05

\begin{tabular}{ll}
\hline PV Module: $\mathrm{W}^{*} \mathrm{H}$ & $0.425 * 0.249 \mathrm{~m} 2$ \\
Module in Series & 2 \\
Total Number of Strings & 2 \\
Total Number of Modules & 4 \\
Total Area & $2.1 \mathrm{~m} 2$ \\
Total Power & $0.2 \mathrm{kWp}$ \\
\hline
\end{tabular}

G. PV Array Summary

$4 \mathrm{PV}$ module of $60 \mathrm{Wp}$ Array oper. $\left(50 \hat{\mathrm{A}}^{\circ} \mathrm{c}, 1000 \mathrm{~W} / \mathrm{m}^{2}\right)$ Pump $=211 \mathrm{~W}, \mathrm{Vmpp}=30 \mathrm{~V}$

H. Operating System: Fixed DC-DC converter

I. Pump Characteristics

Pump: 1 pump

Type: deep well pump

Motor type: DC motor

Nominal operating condition: Pressure $=32.0$ meterW

Flow rate $=1.6 \mathrm{~m}^{3} / \mathrm{h}$

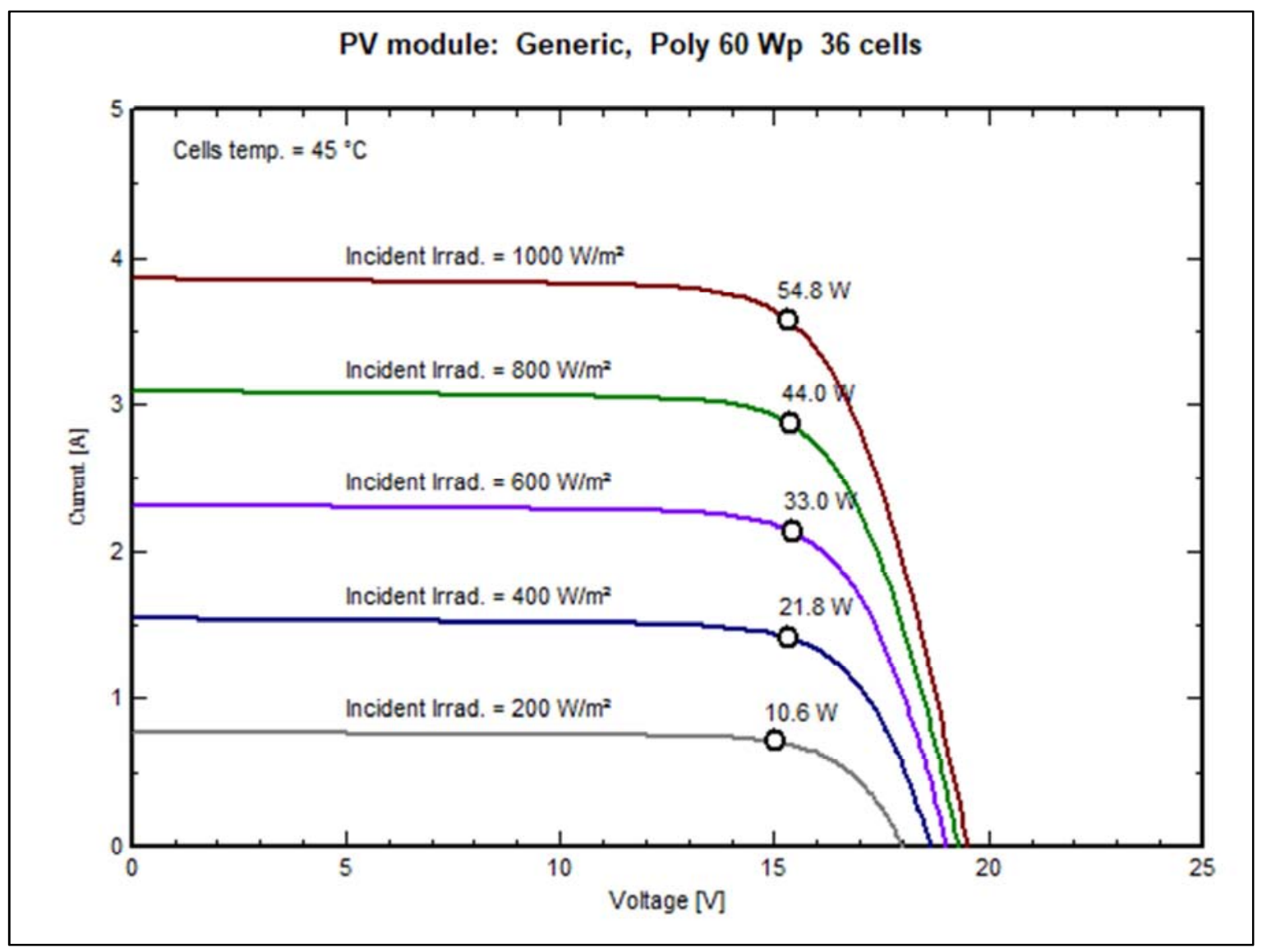

Figure 2. Matching Between PV Array and Pump. 


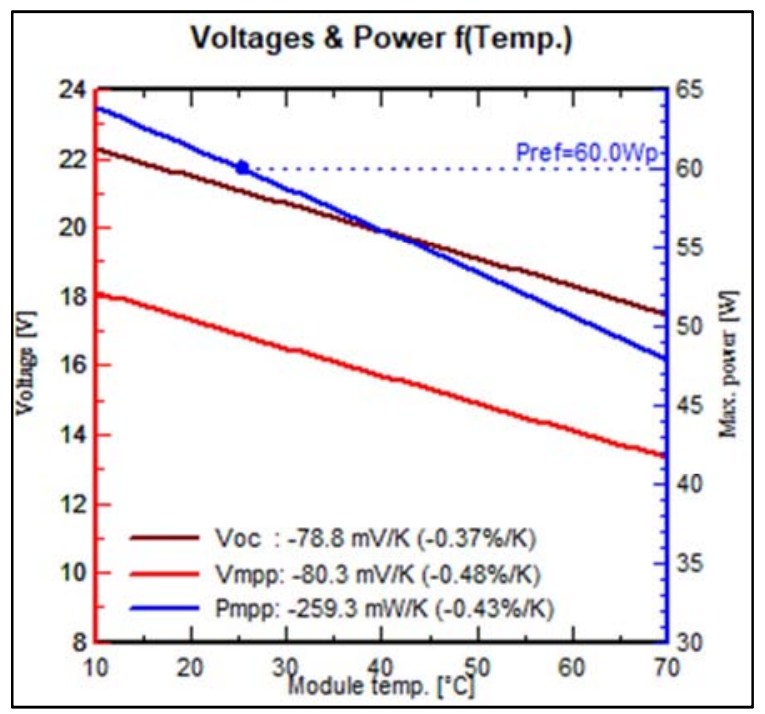

\section{System Design}

The Climate is Sub-tropical monsoon in Bangladesh. Average maximum and minimum winter temperatures are $29 \hat{\mathrm{A}}^{\circ} \mathrm{C}$ and $11 \hat{\mathrm{A}}^{\circ} \mathrm{C}$ respectively; average maximum and minimum summer temperatures are $34 \hat{\mathrm{A}}^{\circ} \mathrm{C}$ and $21 \hat{\mathrm{A}}^{\circ} \mathrm{C}$ respectively. Annual Rainfall 1,194 $\mathrm{mm}$ to 3,454 $\mathrm{mm}$. highest humidity $80 \%$ to $100 \%$ (August-September), lowest $36 \%$ (February-March) [2]. Considering the unique geographic position, the country is located in an ideal position for harnessing Solar Energy to the most optimum level. The following figures (4-9) represent various geographical conditions of Bangladesh, which was recreated for the purpose of simulation in the PVSyst software.

Figure 3. Voltage vs Temperature comparison.

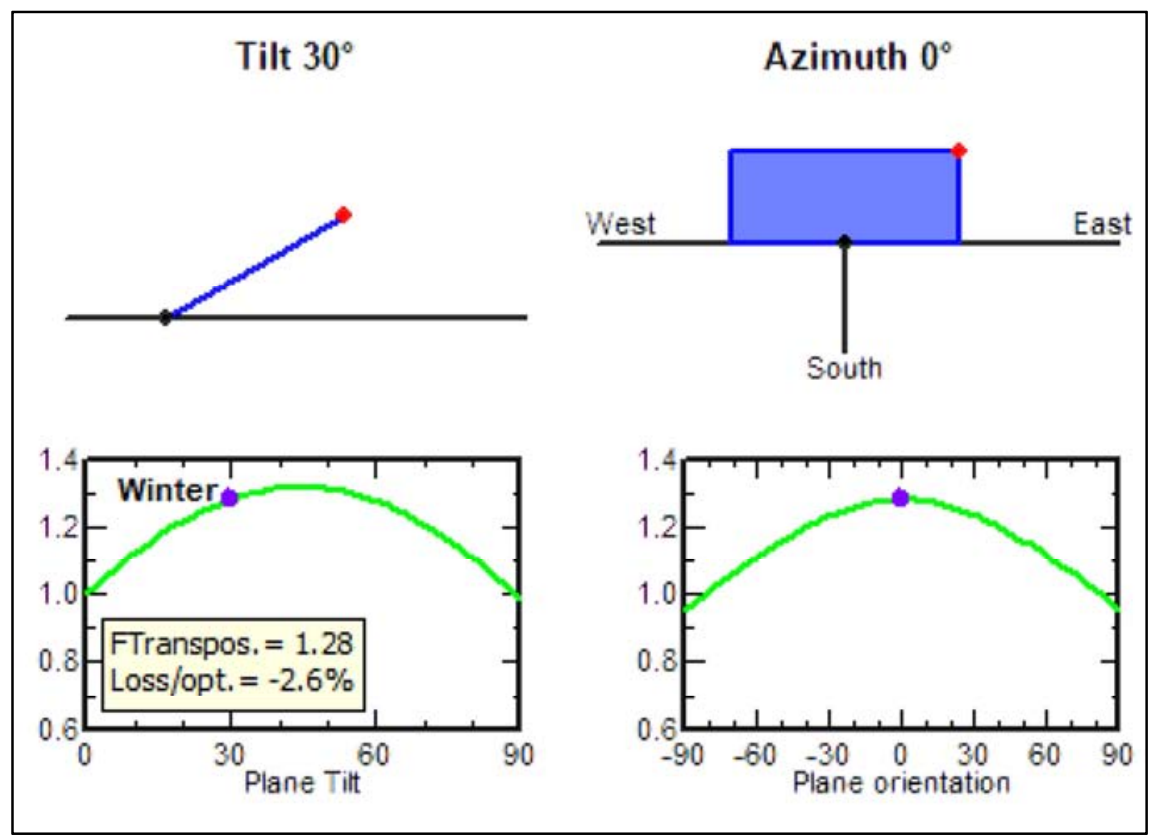

Figure 4. Sun Orientation (Fixed Titled Plane $30^{\circ}$ ).

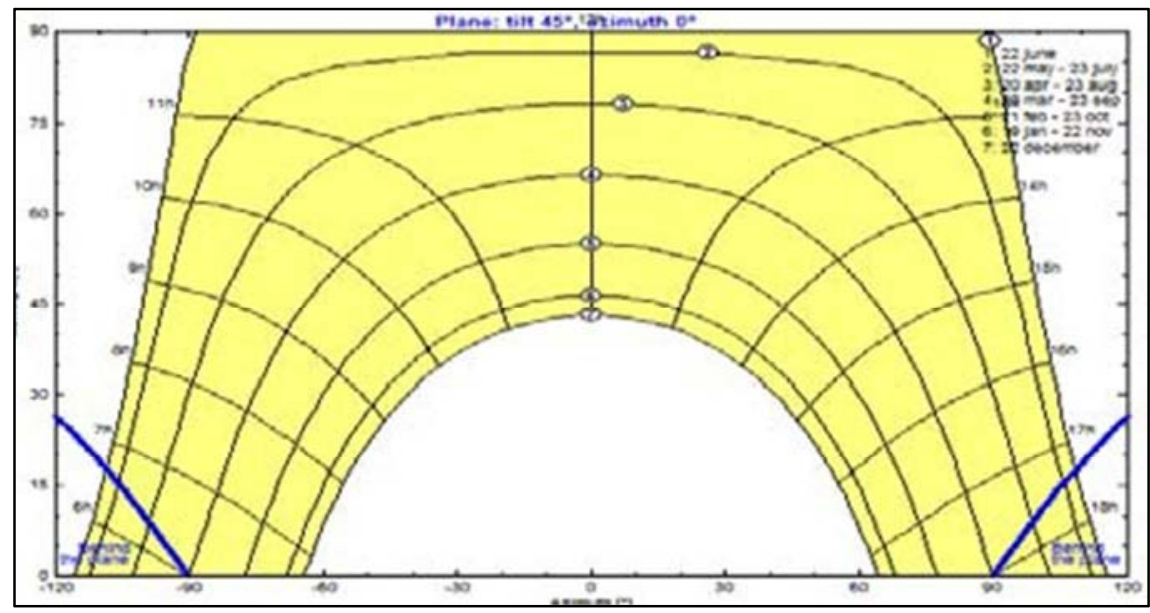

Figure 5. Horizon Line in Bangladesh. 


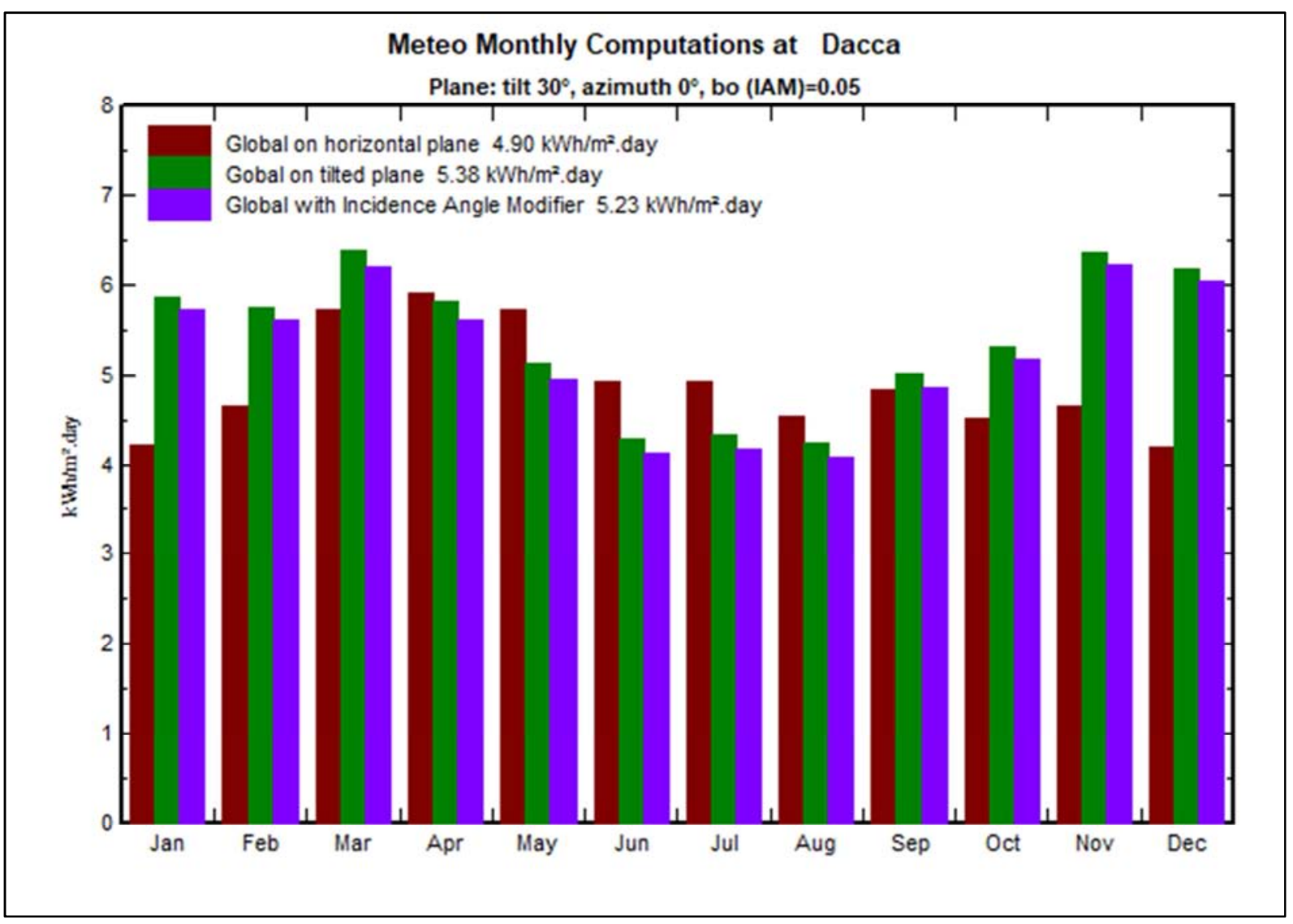

Figure 6. Meteo Monthly Computations for Dhaka.

Geographical site parameters for Dhaka (Dacca) imported from Mateonorm 7.1

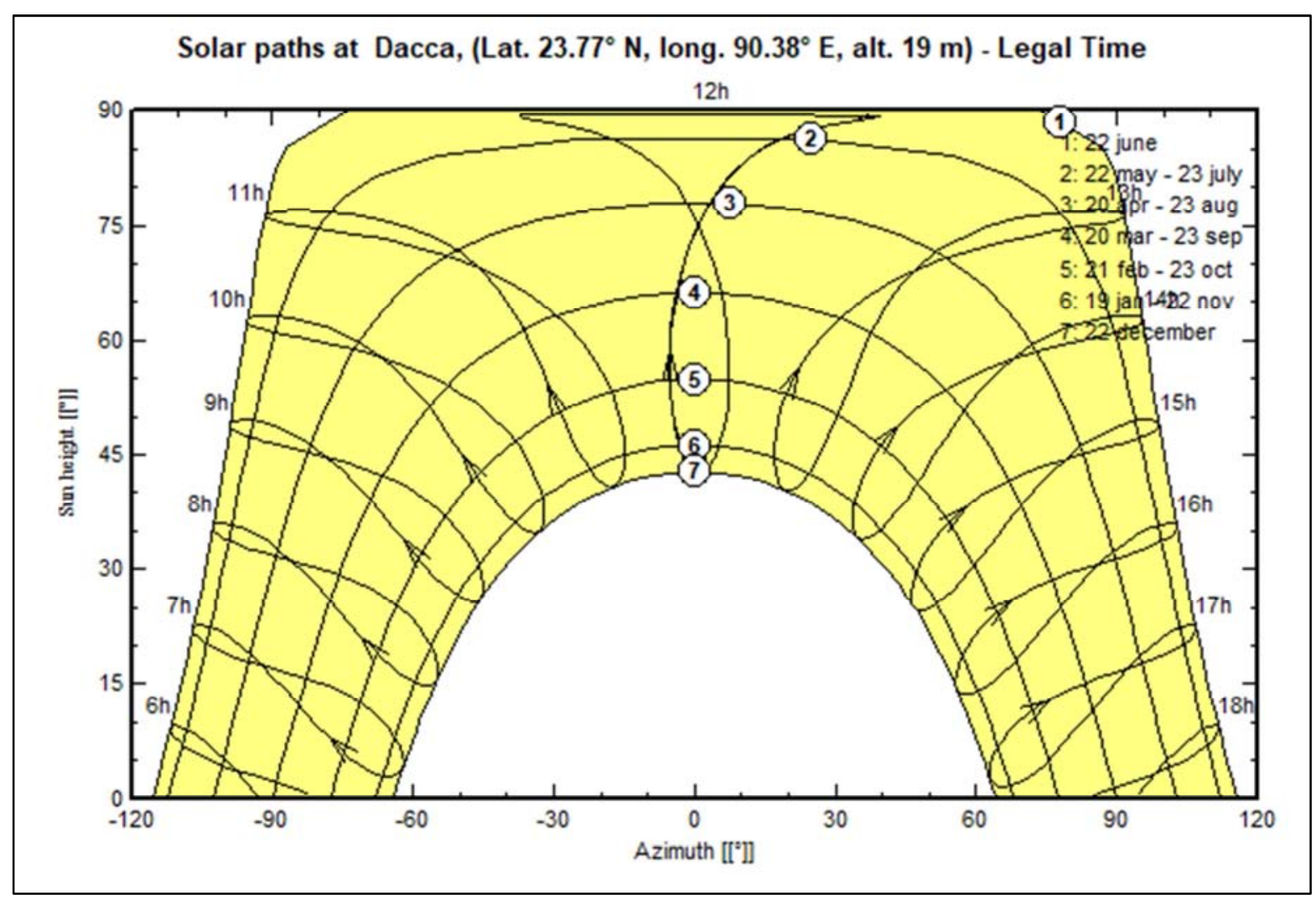

Figure 7. Sun paths diagram Dhaka. 


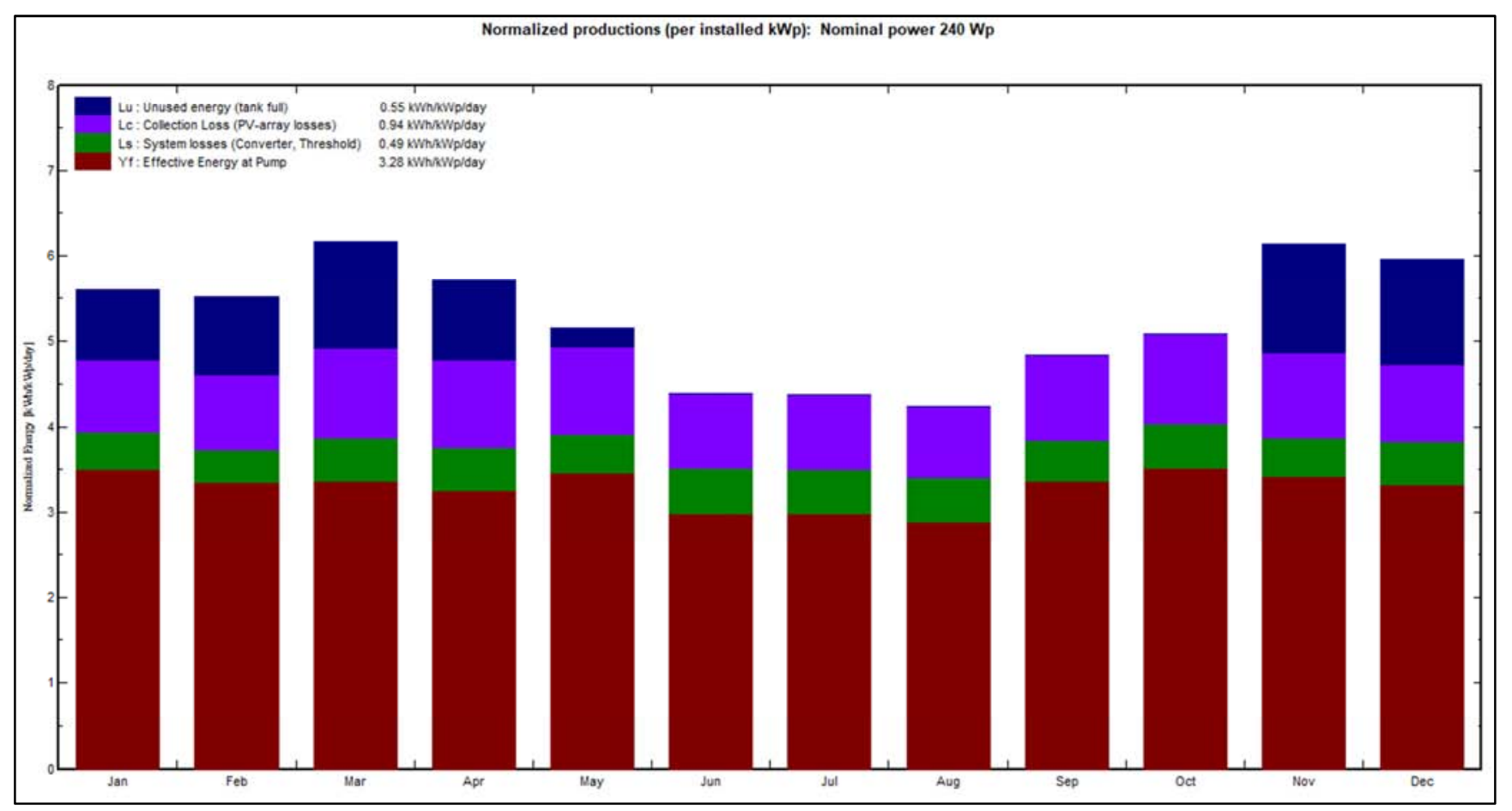

Figure 8. Production rate of each $P V$.

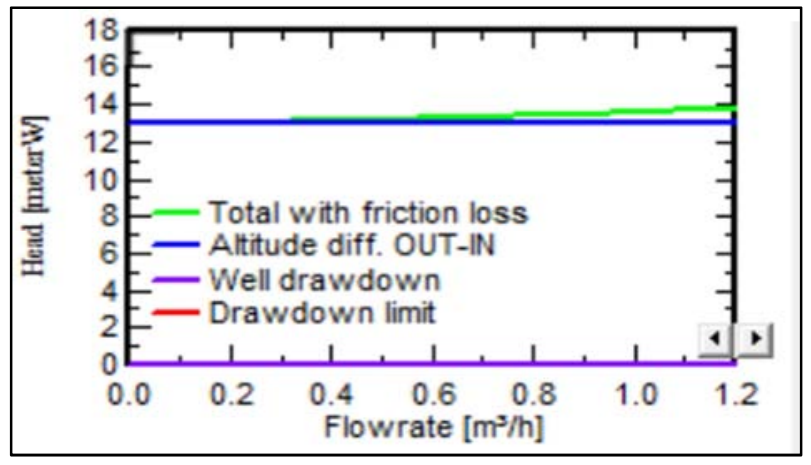

Figure 9. Near Shading of Bangladesh.

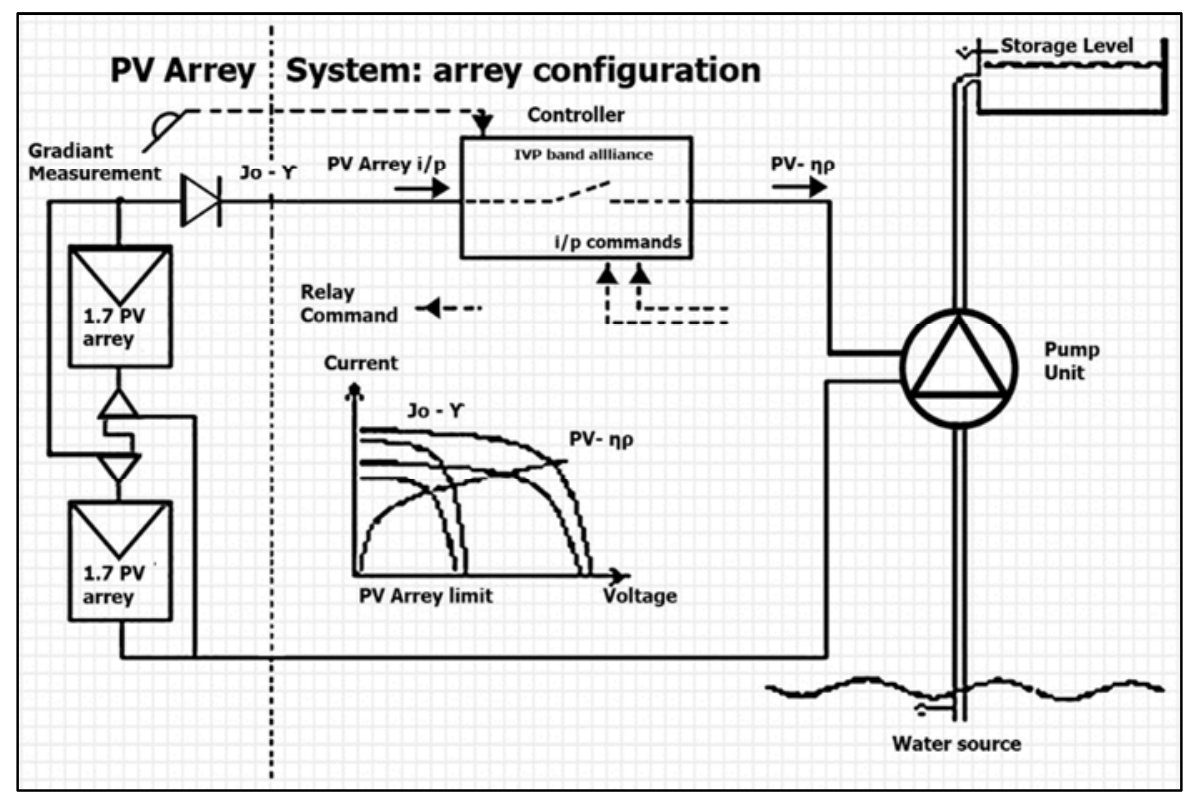

Figure 10. Circuit Diagram of the System. 
The circuit design of the PV system is shown in Figure-10. Actually these figures are generated according to the parameters that are defined in the computational modeling section. The system of array configuration was used in practice for the simulation. Figure-11, 12 and 13 represents the performance graph of simulated system. Figure-14 and figure-15 represents the system architecture within the simulation in block diagram format.

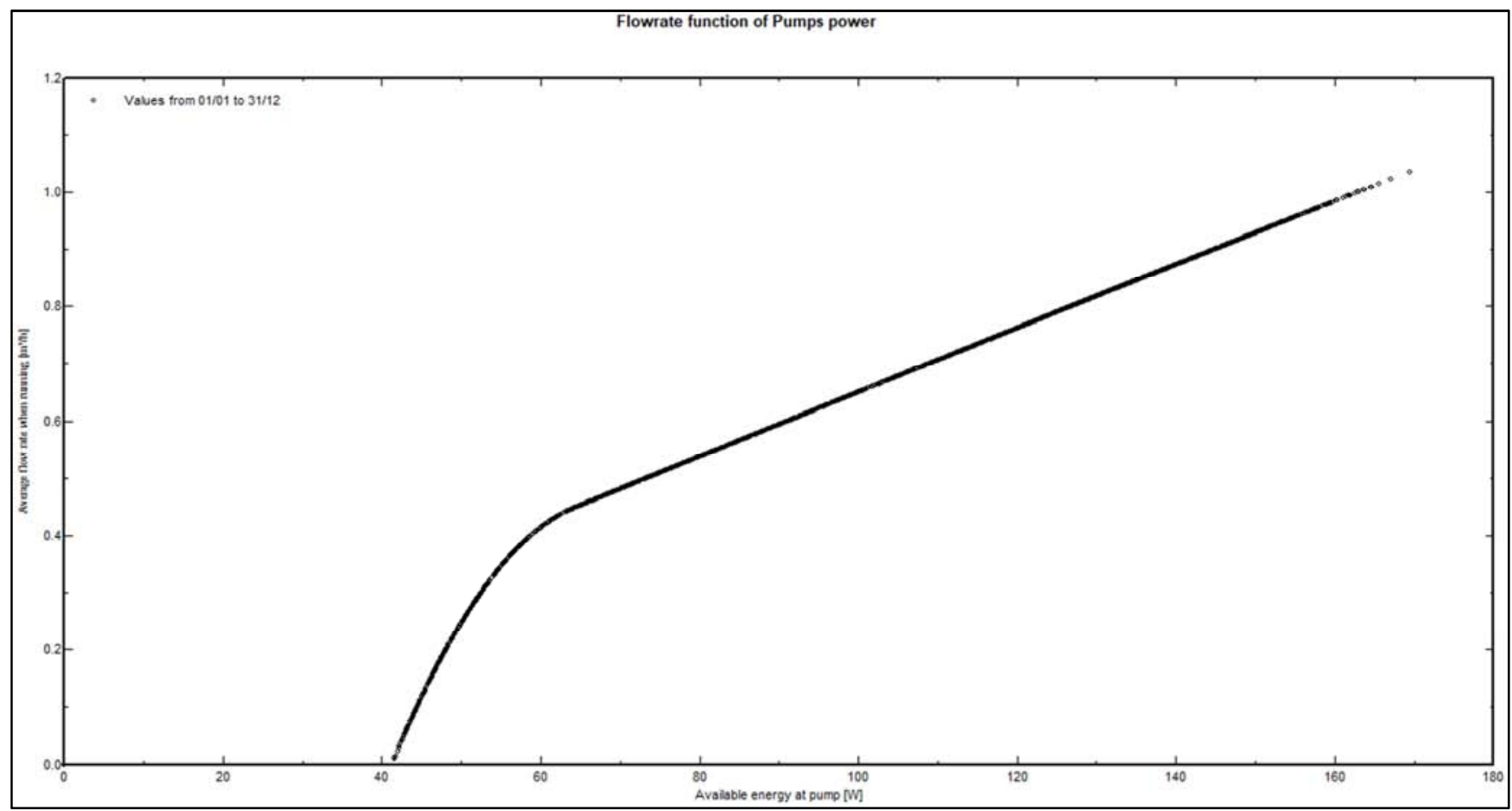

Figure 11. Flowrate function of pumps power.

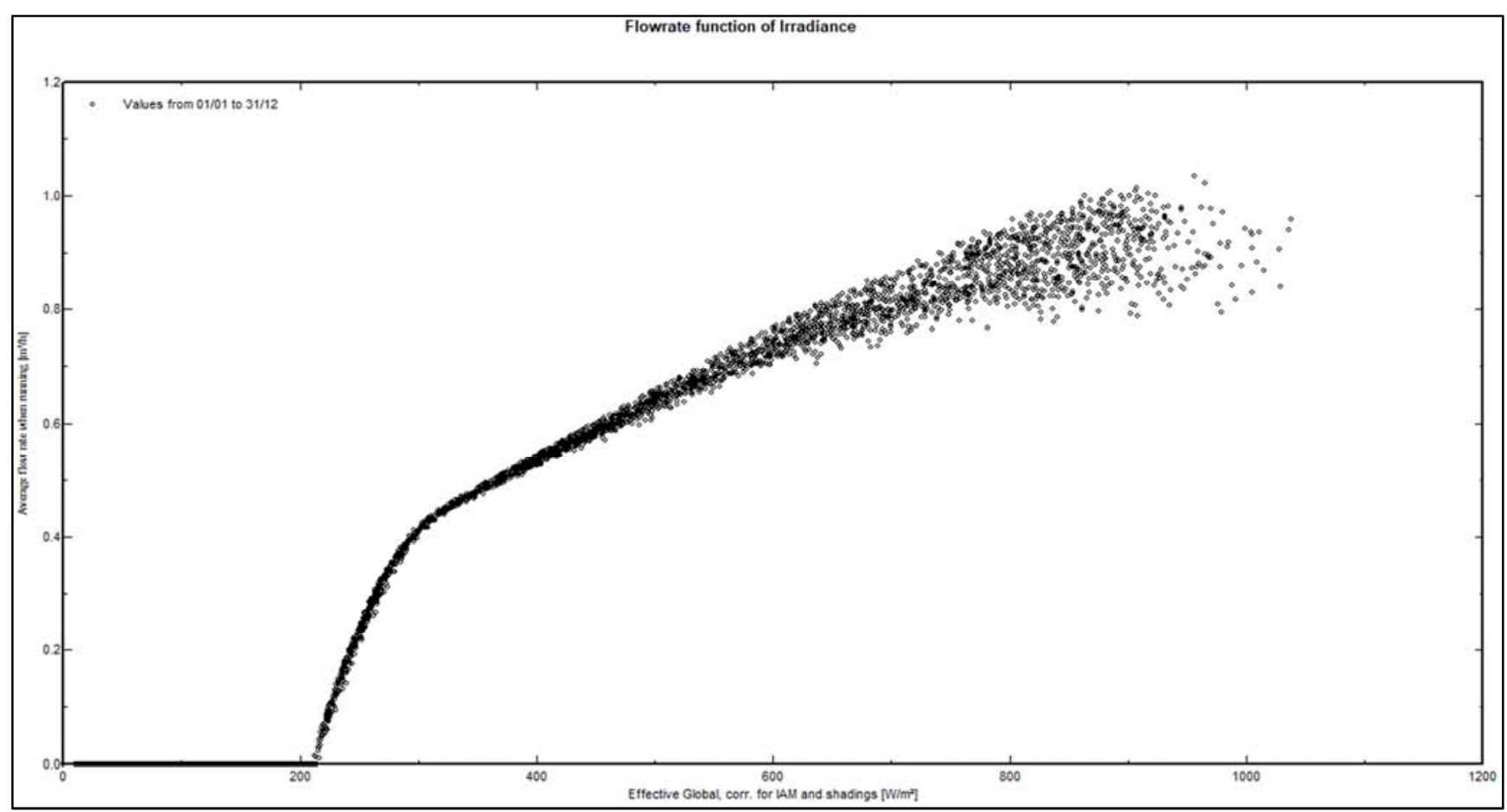

Figure 12. Flowrate function of Irradiance. 


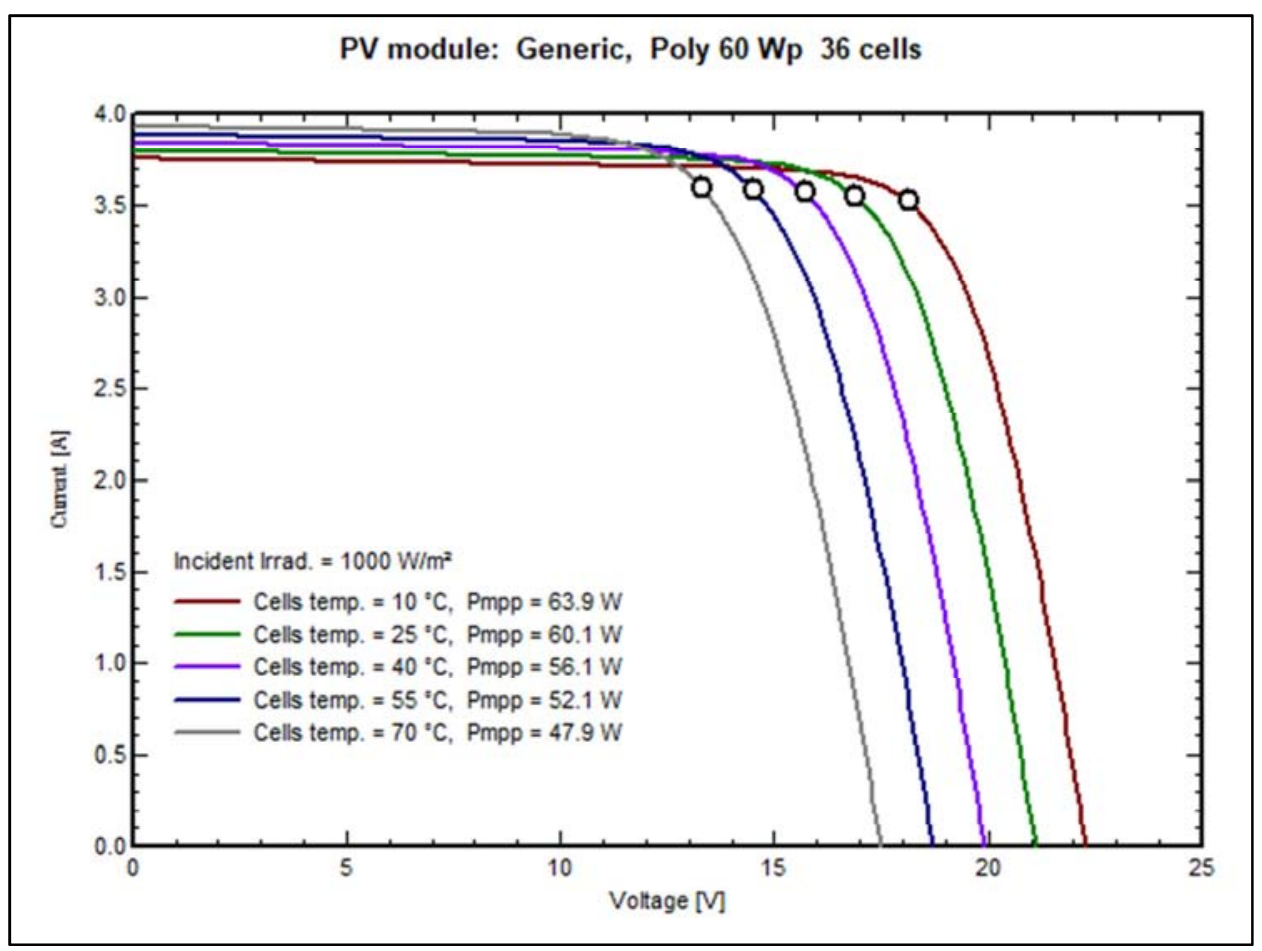

Figure 13. Main Area of Mounting Module.

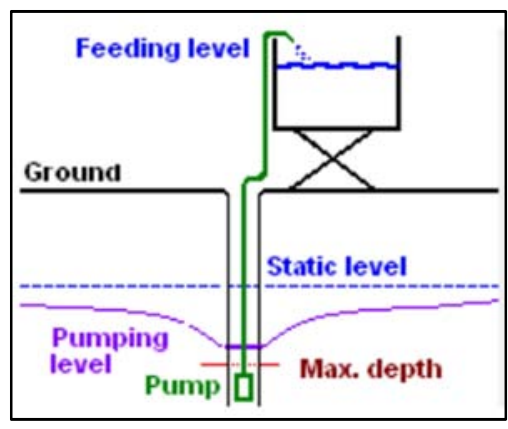

Figure 14. System Performance Overview.

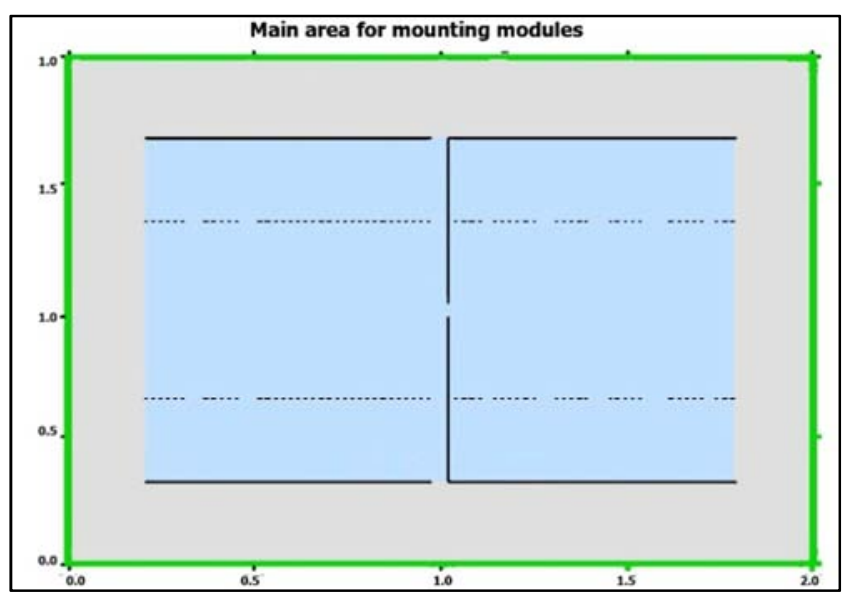

Figure 15. System Architecture.

\section{Performance Analysis}

The following figure 17 represent the simulated data generated by the PVSyst for the configuration. It can be seen that due to the changing movement of the sun rays, there is a variation in response even though a healthy average value is observed throughout. Figure 17 indicates the outcome of water production vs irradiation based on the simulated weather condition Figure 18 gives a visual representation of the array power distribution throughout the system.

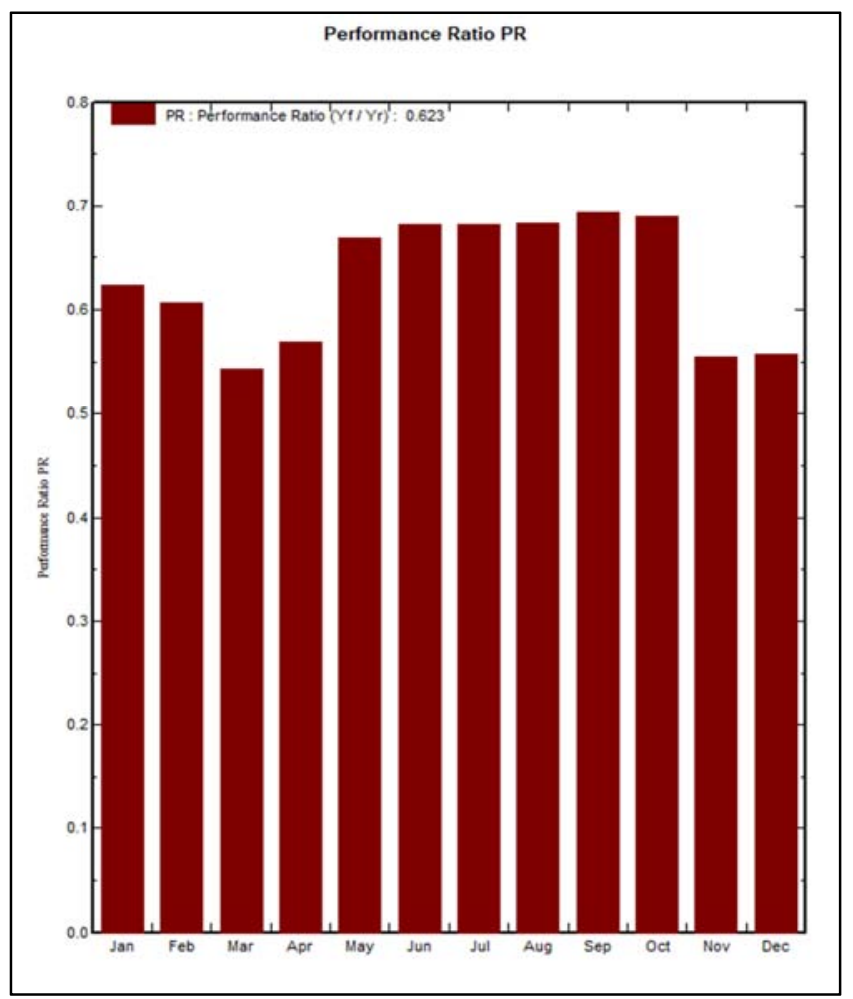

Figure 16. Performance Ratio. 


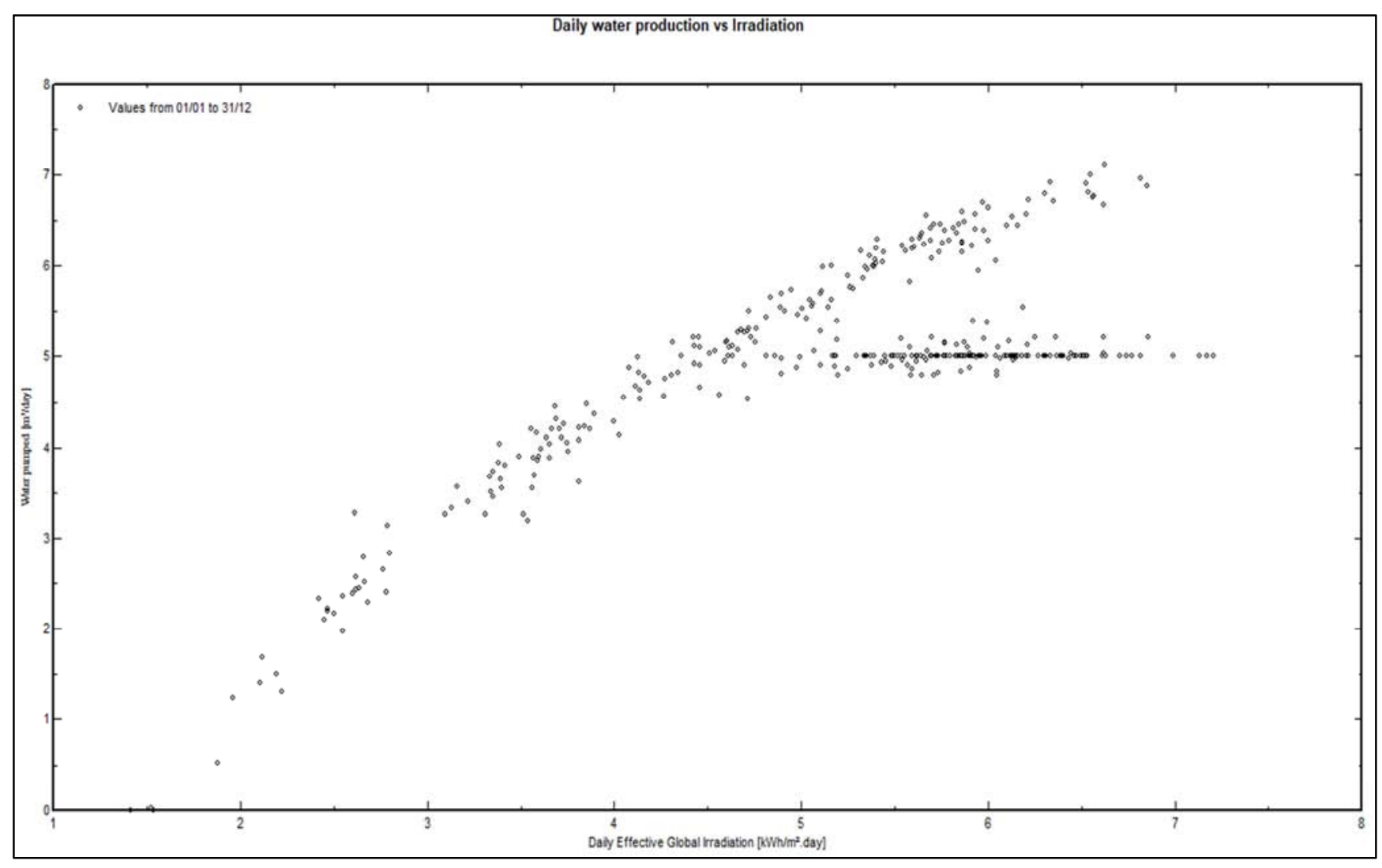

Figure 17. Daily Water Production vs. Irradiation.

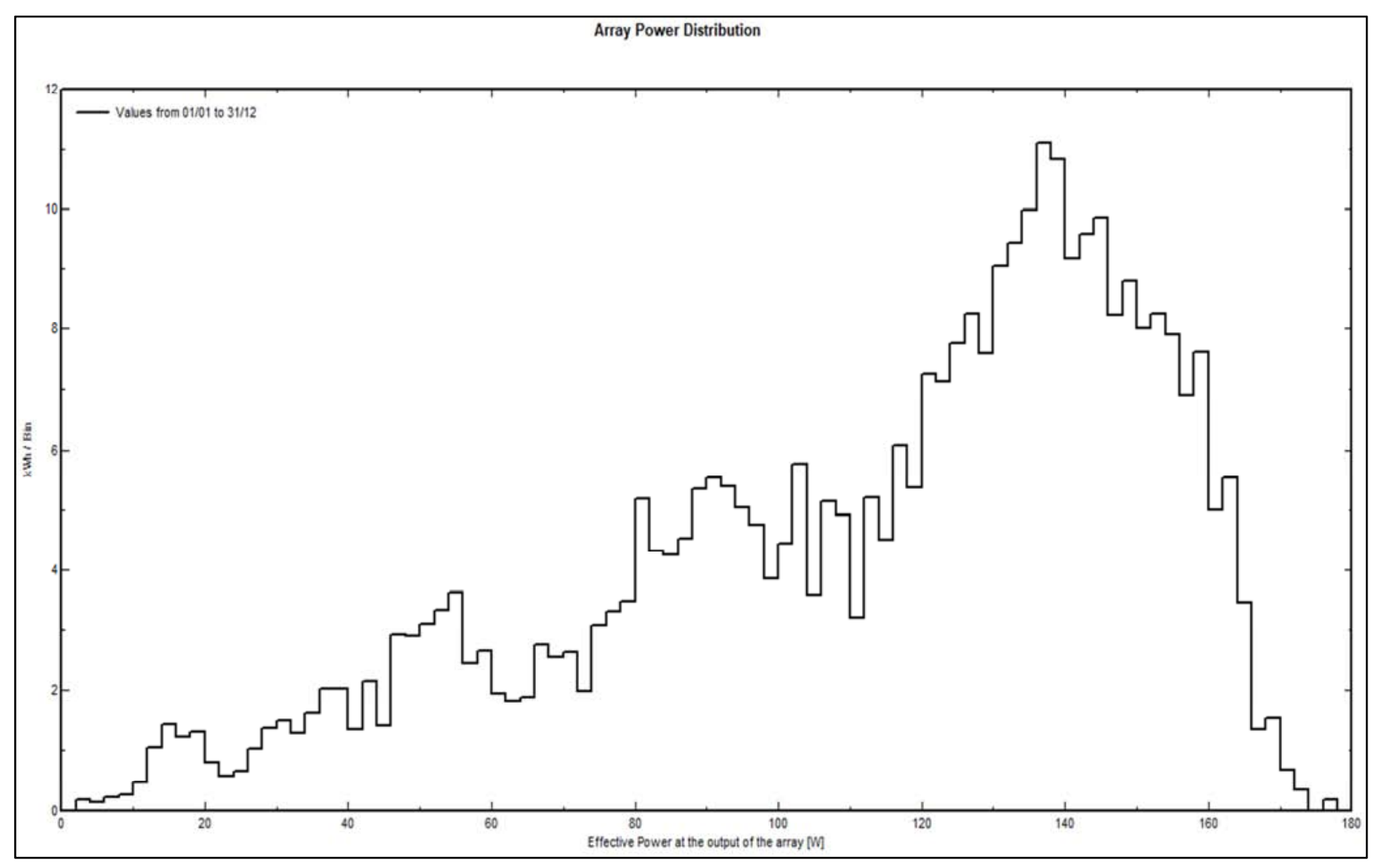

Figure 18. Array Power Distribution. 


\section{Tables}

Table 2. Balances and main results.

\begin{tabular}{|c|c|c|c|c|c|c|c|c|}
\hline & GlobEff & EArrMPP & E PmpOp & ETkFull & H Pump & WPumped & W Used & W Miss \\
\hline & $\mathrm{kWh} / \mathrm{m}^{2}$ & kWh & kWh & kWh & meterW & $\mathrm{m}^{3} /$ day & $\mathrm{m}^{3} /$ day & $\mathrm{m}^{3} /$ day \\
\hline January & 169.6 & 34.36 & 25.98 & 4.780 & 13.40 & 5.271 & 5.000 & 0.000 \\
\hline February & 150.8 & 30.08 & 22.48 & 4.764 & 13.34 & 5.005 & 5.000 & 0.000 \\
\hline March & 186.3 & 35.99 & 24.94 & 6.671 & 13.34 & 5.000 & 5.000 & 0.000 \\
\hline April & 166.2 & 32.25 & 23.43 & 4.770 & 13.28 & 4.841 & 5.000 & 0.000 \\
\hline May & 154.1 & 30.39 & 25.66 & 1.210 & 13.25 & 5.153 & 5.000 & 0.000 \\
\hline June & 126.3 & 25.31 & 21.50 & 0.000 & 13.22 & 4.512 & 5.000 & 0.000 \\
\hline July & 130.4 & 25.99 & 22.16 & 0.000 & 13.23 & 4.462 & 4.576 & 0.424 \\
\hline August & 126.5 & 25.28 & 21.52 & 0.000 & 13.22 & 4.360 & 4.286 & 0.714 \\
\hline September & 140.5 & 27.71 & 24.15 & 0.000 & 13.26 & 5.038 & 4.966 & 0.034 \\
\hline October & 153.3 & 30.02 & 26.09 & 0.000 & 13.29 & 5.345 & 5.000 & 0.000 \\
\hline November & 180.2 & 35.13 & 24.52 & 6.760 & 13.38 & 5.095 & 5.000 & 0.000 \\
\hline December & 180.8 & 36.00 & 24.72 & 7.117 & 13.44 & 5.000 & 5.000 & 0.000 \\
\hline Year & 1865.2 & 368.49 & 287.17 & 36.071 & 13.30 & 4.923 & 4.901 & 0.099 \\
\hline
\end{tabular}

Table 3. Meteo and incident energy.

\begin{tabular}{|c|c|c|c|c|c|c|c|c|}
\hline & GlobHor & DiffHor & T Amb & WindVel & GlobInc & DifSInc & Alb Inc & DifS/GI \\
\hline & $\mathbf{k W h} / \mathbf{m}^{2}$ & $\mathrm{kWh} / \mathrm{m}^{2}$ & ${ }^{\circ} \mathrm{C}$ & $\mathrm{m} / \mathrm{s}$ & $\mathrm{kWh} / \mathrm{m}^{2}$ & $\mathrm{kWh} / \mathrm{m}^{2}$ & $\mathrm{kWh} / \mathrm{m}^{2}$ & \\
\hline January & 130.5 & 48.4 & 17.37 & 0.4 & 173.5 & 54.07 & 1.746 & 0.000 \\
\hline February & 130.3 & 58.6 & 20.77 & 0.6 & 154.6 & 60.86 & 1.744 & 0.000 \\
\hline March & 177.6 & 72.7 & 25.14 & 0.9 & 191.2 & 72.20 & 2.378 & 0.000 \\
\hline April & 177.2 & 84.8 & 27.19 & 1.3 & 171.5 & 79.84 & 2.373 & 0.000 \\
\hline May & 177.8 & 100.9 & 27.88 & 1.0 & 159.9 & 92.36 & 2.378 & 0.000 \\
\hline June & 147.9 & 97.8 & 27.55 & 1.1 & 131.4 & 89.40 & 1.980 & 0.000 \\
\hline July & 152.9 & 94.1 & 28.04 & 1.2 & 135.6 & 85.79 & 2.045 & 0.000 \\
\hline August & 140.4 & 96.3 & 28.25 & 1.0 & 131.2 & 89.53 & 1.879 & 0.000 \\
\hline September & 144.8 & 80.9 & 27.47 & 0.7 & 145.2 & 77.18 & 1.939 & 0.000 \\
\hline October & 140.2 & 70.3 & 26.60 & 0.5 & 157.6 & 70.47 & 1.878 & 0.000 \\
\hline November & 139.2 & 42.7 & 22.70 & 0.3 & 184.1 & 48.01 & 1.864 & 0.000 \\
\hline December & 130.3 & 38.0 & 19.02 & 0.2 & 184.6 & 45.00 & 1.746 & 0.000 \\
\hline Year & 1789.1 & 885.6 & 24.85 & 0.8 & 1920.3 & 864.71 & 23.949 & 0.000 \\
\hline
\end{tabular}

\section{Conclusion}

The concept of this research work came into being while working on a previous project on satellite based soil nutrient study [11] as the high potential of applying solar power as an irrigation tool intrigued us. We further learned more about the country's power systems limitations and aspect of the feasibility of the work while researching on our recent project in electrical safety standards in Bangladesh [12]. From the mathematical modeling and computational modeling, studying the agricultural and economic scenario of Bangladesh we can conclude that our proposed system could be a perfect system for the suction of water from the river for irrigation purpose [13]. The PVSyst simulation software [14] was used for convenience and monetary issues. The storage tank is used so that the farmers would be able to irrigate their land in the night time. And at last we would like to mention that we are now in the fabrication stage of this research project.

\section{References}

[1] Hussain, Intizar. "Pro-poor Intervention Strategies in Irrigated Agriculture in Asia." (2005).
[2] World Bank 2018, World Development Indicators, Washington, DC: World Bank (accessed January 2018), http://databank.worldbank.org/data/home.aspx

[3] Tradingeconomics.com. (2018). Bangladesh Agricultural Irrigated Land Percent of Total Agricultural Land. [online] Available at: http://www.tradingeconomics.com/bangladesh /agricultural-irrigated-land- percent-of-total-agricultural-landwb-data.html [Accessed 2 Feb. 2018].

[4] Pereira, Luis Santos, Theib Oweis, and Abdelaziz Zairi. "Irrigation management under water scarcity." Agricultural water management 57.3 (2002): 175-206.

[5] Johansson, Robert C., et al. "Pricing irrigation water: a review of theory and practice." Water Policy 4.2 (2002): 173-199.

[6] Bangladesh Renewable Energy Report. 2007, Asian and Pacific Centre for Transfer of Technology Of the United Nations - Economic and Social Commission for Asia and the Pacific (APCTT-UNESCAP) This report was prepared by Prof. Dr. Neem Chandra Bhowmik, Director Renewable Energy Research Centre, University of Dhaka (Phone 9677125, 9661900/4570, Email: rercdu@yahoo.com) under a consultancy assignment given by the Asian and Pacific Centre for Transfer of Technology (APCTT).

[7] Khan, M. J., M. T. Iqbal, and S. Mahboob. "A wind map of Bangladesh." Renewable energy 29.5 (2004): 643-660. 
[8] Ahmed, Irshad, John Decker, and David Morris. How much energy does it take to make a gallon of soydiesel?. Washington, DC: Institute for Local Self-Reliance, 1994.

[9] Tradingeconomics.com. (2018). Bangladesh Agricultural Irrigated Land Percent Of Total Agricultural Land. [online] Available at:

http://www.tradingeconomics.com/bangladesh/agriculturalirrigated-land- percent-of-total-agricultural-land-wb-data.html [Accessed 2 Feb. 2018].

[10] en.banglapedia.org. (2018). River and Drainage System Banglapedia. [online] Available at: http://en.banglapedia.org/index.php?title=River_and_Drainage System [Accessed 2 Feb. 2018].

[11] Saleh, S. M., Islam, S. R., Hossain, M. I., \& Pavel, K. A. A. Study of Bangladesh Soil Nutrient over Satellite Images.

[12] Islam, S., Huque, M., Khan, L. and Hossain, M. (2017). An experimental thermographic safety audit focusing on temperature rise vs load in electrical installations in a Bangladesh garments factory. 2017 4th International Conference on Advances in Electrical Engineering (ICAEE).

[13] Mermoud, André. "Pump behaviour modelling for use in a general PV simulation software." Proceedings of the 19th European PV Solar Energy Conference, Paris. 2004.

[14] Files.pvsyst.com. (2018). Overview > General description of the PVsyst Software. [online] Available at: http://files.pvsyst.com/help/general descr.htm [Accessed 2 Feb. 2018].

\section{Biography}

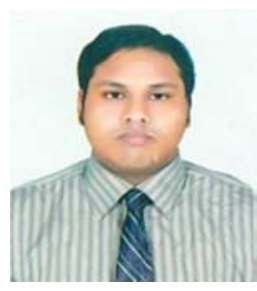

Md. Imran Hossain, graduated from in Electrical and Electronic Engineering and completed his MBA in from American International University Bangladesh. He received the Chairman's Gold Medal during convocation. He is currently working with NewTech Bangladesh Ltd.

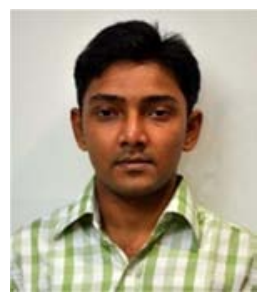

S. M. Raisul Islam, graduated from American International University Bangladesh in Electrical and Electronic Engineering and completed his MBA in Management Information Systems from University of Dhaka. He worked with Li \& Fung (Bangladesh) Ltd. on electrical safety audits and Leveraging ICT project under Ministry of Posts, Telecommunication and Information Technology, Bangladesh. 